IZA DP No. 8325

Should I Stay or Should I Go?

An Investigation of Graduate Regional Mobility in the UK and its Impact upon Early Career Earnings

Michael Kidd

Nigel O'Leary

Peter Sloane

July 2014 


\title{
Should I Stay or Should I Go? An Investigation of Graduate Regional Mobility in the UK and its Impact upon Early Career Earnings
}

\author{
Michael Kidd \\ Queensland University of Technology \\ Nigel O'Leary \\ Swansea University and NILS, Flinders University \\ Peter Sloane \\ Swansea University, NILS, Flinders University and IZA
}

Discussion Paper No. 8325

July 2014

IZA

P.O. Box 7240

53072 Bonn

Germany

Phone: +49-228-3894-0

Fax: +49-228-3894-180

E-mail: iza@iza.org

Any opinions expressed here are those of the author(s) and not those of IZA. Research published in this series may include views on policy, but the institute itself takes no institutional policy positions. The IZA research network is committed to the IZA Guiding Principles of Research Integrity.

The Institute for the Study of Labor (IZA) in Bonn is a local and virtual international research center and a place of communication between science, politics and business. IZA is an independent nonprofit organization supported by Deutsche Post Foundation. The center is associated with the University of Bonn and offers a stimulating research environment through its international network, workshops and conferences, data service, project support, research visits and doctoral program. IZA engages in (i) original and internationally competitive research in all fields of labor economics, (ii) development of policy concepts, and (iii) dissemination of research results and concepts to the interested public.

IZA Discussion Papers often represent preliminary work and are circulated to encourage discussion. Citation of such a paper should account for its provisional character. A revised version may be available directly from the author. 


\section{ABSTRACT}

\section{Should I Stay or Should I Go? \\ An Investigation of Graduate Regional Mobility in the UK and its Impact upon Early Career Earnings *}

This paper uses HESA data from the Destination of Leavers from Higher Education survey 2003/04 to examine whether more mobile students in terms of choice of institution and location of employment earn more than those who are less mobile. The clear finding is that mobility is associated with superior earnings outcomes, but principally through mobility as it relates to students extending their horizon of job search. A bivariate probit analysis also confirms that there is a positive relationship between regional mobility both in the choice of attending university and the choice of where to take up employment.

JEL Classification: J24, J31

Keywords: graduates, location by residence, academic institution and employment, earnings

Corresponding author:

Nigel O'Leary

Swansea University

Singleton Park

Swansea SA2 8PP

Wales

United Kingdom

E-mail: n.c.oleary@swansea.ac.uk

\footnotetext{
* The DLHE data was made available from the Higher Education Statistics Agency through the Welsh Government, although neither bears responsibility for the analysis or interpretation of the data reported here. Financial support from the ESRC (grant no: RES-591-28-0001) is gratefully acknowledged by O'Leary.
} 


\section{Introduction}

A wide-ranging body of research has investigated the issue of worker mobility and the general consensus is that more mobile individuals are able to secure superior labour market outcomes. More effective job search is seen as a crucial mechanism through which such superior outcomes are realised. Stylised facts are that the propensity to migrate is related to human capital accumulation (see Sjaastad, 1962 and Becker, 1964), gender and ethnic origin. An area of this migration literature that has received a growing level of attention is the mobility of graduates within the workforce. Given the correlation between human capital accumulation and mobility, it is natural to suppose that this subset of the population would be amongst the most mobile. In the UK, this has fostered much recent work using data from the Higher Education Statistics Agency (HESA) in particular but much of this research has been focussed upon the issue of how mobility affects regions.

The focus of this current research though is to examine how the issue of mobility affects individuals as opposed to regions or areas. There are three factors to consider. First, do individuals change location to undertake their studies? Second, do they move from location of study to take up employment? Third, do they return home after completing their studies? Each of these decisions may have different consequences for employment outcomes. It is well known that graduates earn an earnings premium over non-graduates (see, for instance, O'Leary and Sloane, 2005 and 2008, and Walker and Zhu, 2011). The general theoretical argument holds that a greater initial migration propensity should increase subsequent migration propensities and by expanding the area of search also increase real wages in the long run. Such propensities will increase with the ability of the student and the ranking of their institution. After a student has moved, the psychological and emotional costs of further movement may be relatively lower than for those who choose to study in their home area (DaVanzo, 1976 and 1983). However, cultural and institutional factors may also play a role (Faggion et al., 2007).

In this paper we model the mobility patterns of graduates and labour market outcomes some 3.5 years after graduation using the HESA Destinations of Leavers from Higher Education (DLHE) Longitudinal Survey of the $2003 / 04$ cohort in order to ascertain whether those who move out of their region of residence to study or to take up employment do better than those who stay. We restrict the analysis to first degree graduates born in or resident in the UK and ignore those who do not proceed straight into employment after graduation and the few graduates who take up employment abroad. We then follow the 2003/04 cohort into the labour market and establish the extent to which earnings differ according to region of origin, type of institution, type of degree, 
degree classification and type of mobility. The implicit assumption is that salary after 3.5 years are a good predictor of lifetime earnings and available evidence suggests that this is indeed the case as the vast majority of workers tend to remain in the same UK region and the same broad occupational grouping for very long periods. Thus, individuals who choose to enter a particular occupation in a particular region on graduating from a higher education institution do so with a view to staying in that chosen occupation and region for life (Naylor et al., 1998). Given the evidence presented by de Grip et al. (2008) on the persistence of graduate disadvantage after early career mismatch, we can be confident that the early career opportunities analysed in this current work will also be an important indicator of lifetime opportunities and as such early career disadvantage is likely to translate into inferior long-term outcomes.

\section{Previous Literature}

A number of previous studies suggest that the probability of studying at university is influenced by the distance between place of domicile and the nearest university. However, whether this relationship is causal is less certain, since universities may be located in areas where the more affluent are numerous and this group is more likely to attend university than the less affluent. In any event we cannot examine this question as our sample is limited to those who have already made the decision to attend an institution of higher education. Using Swiss data Denzler and Wolter (2011) have also shown, however, that distance to university influences choice of subject/faculty and institution. If choices among these are limited and a substantial number of students are unable or unwilling to attend a local institution, a lack of student mobility will reduce the likelihood of achieving optimal productive and allocative efficiency. In an early UK study, Osborne et al. (1987) traced the employment experience of a cohort of Northern Ireland students who entered higher education in 1979. They noted the roles of gender, religion, academic discipline and degree class. The Province is found to suffer from a serious net loss of graduate labour, and especially of those with good degrees. A similar situation appears to apply in Wales (see Bristow et al., 2011). Faggion, McCann and Sheppard (2007) use HESA data up to 2000/01 to examine the sequential migration behaviour of Scottish and Welsh students in terms of their home location, that of their academic institution and their place of employment. They find that the on-migration behaviour of individuals is positively related to previous migration history and the level of human capital acquired, the latter posited to improving the ability of individuals to gain better jobs in a wider set of locations (see also DaVanzo, 1983). In a later paper, Faggion and McCann (2009) examine the relationship between inter-regional flows of graduates and regional innovation performance. The results for Great Britain as a whole are dependent on whether London is included and Scotland excluded. This has 
implications for our analysis, suggesting that it is necessary to split England into its constituent regions in order to make it more comparable with Scotland, Wales and Northern Ireland. Hoare and Corver (2010) take into account the fact that some regions are better provided with universities than others in relation to their size and note that this has led to calls for university provision to be extended to unrepresented population centres. In terms of graduate recruitment, London is a surplus region with graduate employment exceeding its student population share, while Yorkshire and Humberside and Scotland are balanced and the remaining regions in deficit.

There are a various underlying factors which are likely to influence the degree of mobility. The ability of a university to retain its graduates in its own locality will be a function of its size relative to that of its local labour market. Small university towns, such as St Andrews, Bangor and Aberystwyth are unlikely to retain graduates to the same extent as large metropolitan universities such as those in Birmingham, Liverpool and Manchester. For the US, Winters (2012) defines 41 metropolitan areas as 'college towns' on the basis that the share of the population enrolled in college is more than one standard deviation greater than the mean across all metropolitan areas. Differences in employment outcomes after graduation between stayers and leavers in college towns are then compared and both earnings and occupation level are found to be lower for stayers compared to leavers. Hoare and Corver (2010) also note that higher education (HE) participation rates varied in 2001/02 from $24 \%$ in the North East to $36 \%$ in Scotland. Regional HE capacity also varied substantially, such that universities in the Eastern region were able to accommodate only $44 \%$ of the local supply of qualified students, whereas in the East Midlands the local capacity was $130 \%$ of the local supply of qualified students. University catchments also vary, such that while $91 \%$ of Scottish domiciled students study there, the corresponding figure is only $31 \%$ in the South West. There will be some relationship between these figures and graduate mobility. Abreu, Kitson and Wales (2008) analysed the migration patterns of over 200,000 graduates in 2005/06 and found that $25 \%$ stayed in the region of domicile. Of those who migrated $47 \%$ returned home, $16 \%$ stayed in the region of the academic institution and $37 \%$ moved to a new region.

Public sector employment is an important source of graduate employment, especially outside London (Wright, 2011). Personal characteristics, such as gender and ethnic group influence migration flows, as does the subject studied. High performers are more likely to move, but mature students less so. Migration is predominantly to richer, more highly skilled urban areas with high concentrations of younger people. Similar results were obtained by Mosca and Wright (2010), who note that male graduates are more likely to migrate than female graduates, as are those with a 
better degree, those from a Russell Group institution and those who had already moved region to study. Wright (2011) notes that while over one third of graduates are located in London and the South East there has been a spreading out of young graduates to the North and Midlands in the last decade or so, but these are disproportionately employed in the public sector, which is graduate intensive.

A number of papers have examined the financial returns to UK graduates. Using data from the Labour Force Survey (LFS) O'Leary and Sloane (2005) find that, while degrees as a whole lead to substantial increases in lifetime earnings there is a substantial heterogeneity in returns across disciplines. Further, the returns are greater for women than for men. In a further paper (O'Leary and Sloane, 2008) they show that there are substantial regional variations in the returns to higher education. However, adjusting for regional differences in the cost of living (including housing costs) substantially reduces these differences. Using more recent LFS data Walker and Zhu (2011) were able to confirm the results obtained by O'Leary and Sloane (2005). Degree class, only more recently available in the LFS, is also shown to have a large effect regardless of discipline. Chevalier (2011) uses the HESA longitudinal data, as in this study, to examine differences in early labour market attainment by subject of graduation, confirming many of the above results. However, unlike this paper, he does not focus on differences across regions or on the migration decisions of individuals investing in higher education.

The literature between graduate outcomes and their mobility is far less well-developed. One exception is Abreu, Faggion and McCann (2014), who examine the impact of industrial mobility on earnings and job satisfaction, using HESA longitudinal data. They find that those who change both location and industry fare worse in the short run than non-movers, both with respect to earnings and job satisfaction while those who change location but not industry do better than non-movers. However, the focus on migration by Abreu et al. is only concerned with movements that occur when graduates change jobs and is markedly different from the approach followed in this paper. Here, we use the same data source but focus on place of residence, place of study and place of employment in a more general examination of graduate mobility in a regional context.

\section{Data}

The data used come from the Destinations of Leavers from Higher Education (DLHE) 2003/04 survey, conducted by the Higher Education Statistics Agency (HESA). The survey has been organised in two stages, the first being a census of individuals who have completed higher education courses in the 
UK. This stage was carried out approximately six months after the course ended as is referred to as the Early Survey. The second stage, referred to as the Longitudinal Survey, is a follow-up survey that looks at the destinations of leavers up to 3.5 years after they graduated. In contrast to the Early Survey, the Longitudinal Survey is not a census but is instead based on a sample of the students who responded to the corresponding Early Survey. In its current form, the DLHE survey has run since $2002 / 03$, with the most recent data being available for $2008 / 09 .{ }^{1}$ Thus, while more contemporary versions of the DLHE are available we wanted to avoid conflating recessionary effects with graduate premium and mobility effects. Using DLHE 2003/04 allows for the most recent version of the survey that is not affected by the 2007 financial crisis and subsequent recession and all decisions, from going to university to taking up employment, would have been made at times of continuous economic growth.

The information contained within DLHE contains a rich history of data that allows a profile of individual movement and attainment to be built. Relevant to the analysis conducted here, this includes a range of personal characteristics (such as age, gender and ethnicity), details about the university attended and the degree course studied, employment circumstances (whether employed, self-employed etc.) after completion of study and job details (such as salary and occupation). Crucially for the mobility analysis, the data also contains an indication of location at three points in time: the home domicile region is recorded before entry to university; we know the region of the university attended; and finally, the region of employment 3.5 years after graduation is also recorded. While the DLHE survey will include leavers with undergraduate and postgraduate degrees, the focus in the analysis that follows is only on those who have graduated with an undergraduate degree. Not only does this allow for a cleaner comparison when we analyse the labour market outcomes of graduates, but the data does not allow us to identify mobility between undergraduate and postgraduate study, which do not have to be at the same institution or indeed region. To avoid introducing this bias into the analysis, the sample is restricted to undergraduate degree holders only. After removing observations for which there was missing data, 7,901 individuals were identified who had a complete migration history. Of these, 3,717 also provided earnings data.

\section{Methodology}

Consider the situation facing a student $j$ in her choice of where to attend university. ${ }^{2}$ If she moves from her home domicile region to a university in an alternative region then she is identified as a

\footnotetext{
${ }^{1}$ Prior to $2002 / 03$ the survey was known as the First Destination Survey.

${ }^{2}$ For grammatical simplicity we will assume that student $j$ is female, but note that the empirical estimation that follows will be conducted for both males and females.
} 
mover and we can define an indicator variable $I_{1 j}$ that takes a value of 1 to denote this fact. In the other instance, that is when she attends a university in the same region as her domicile, $I_{1 j}$ takes a value of 0 . When we look at the outcome of where student $j$ is employed, a second indicator variable $I_{2 j}$ takes the value of 1 if she works in a different region to that in which the university she attended is located. When employment and university are in the same geographical region $I_{2 j}$ takes the value of 0 . With this in mind, we can subsequently model the propensity of student $j$ to migrate, both from domicile to university, and from university to employment, in the following way:

$$
\begin{aligned}
& I_{1 j}^{*}=x_{j} \beta+\epsilon_{1 j} \\
& I_{2 j}^{*}=z_{j} \gamma+\epsilon_{2 j}
\end{aligned}
$$

where for student $j I_{1 j}^{*}$ and $I_{2 j}^{*}$ are unobserved latent variables and instead we observe only $I_{i j}=1$ if $I_{i j}^{*}>0$ and $I_{i j}=0$ otherwise (for $i=1,2$ ). The vectors $x$ and $z$ contain those variables which are known to influence the decision of student $j$ to migrate, $\beta$ and $\gamma$ are conformable vectors of returns to these characteristics and $\varepsilon_{1}$ and $\varepsilon_{2}$ are normally distributed residual error terms. Under the assumption that [1] and [2] are not estimated independently but rather jointly, such that those determinants of whether a student moves to university also determine whether the student subsequently moves from university, then equations [1] and [2] could be estimated via a bivariate probit such that Cov $\left(\epsilon_{1}, \epsilon_{2}\right)=\rho$. As a result, more efficient estimates of the migration processes can be obtained by taking into account such a correlation structure within the bivariate response than if estimates were derived from a probit model for each response separately. Given that the determinants to migration in both stages are not identical, that is the characteristics in vectors $x$ and $z$ are not exactly the same, [1] and [2] are most appropriately estimated by a seemingly unrelated regression version of the bivariate probit.

Given the distinction between those who (potentially) move in the first stage to university and those who (potentially) move in the second stage to employment, the following classification is made based upon first and second-stage movements:

A. Non-Movers: those who attend university and work in the same region as their home domicile $\left(I_{1}=0, I_{2}=0\right)$;

B. Move-Returners: those who move from their home domicile region to attend university but subsequently return to work $\left(I_{1}=1, I_{2}=1\right)$; 
C. Stay-Leavers: those who remain in their home domicile region to attend university but subsequently leave for employment in another region $\left(I_{1}=0, I_{2}=1\right)$;

D: Leave-Stayers: those who move from their home domicile region to attend university and subsequently remain in this same region for employment $\left(I_{1}=1, I_{2}=0\right)$;

E. Non-Returning Double-Movers: those who move from their home domicile region to attend university and subsequently move again to another region (which is not their home domicile) for employment $\left(I_{1}=1, I_{2}=1\right)$.

Note that groups $B$ and $E$ both involve a double movement but $B$ involves a movement back to the home domicile while E involves a movement to a region other than the home domicile. Given this classification, we can label groups B through $E$ as movers (M), where each classification is a distinctly identifiable group of movers, and group $A$ as non-movers $(\mathrm{N})$ and the earnings of movers and nonmovers can be estimated in the following way via the quantile regression estimator (see Koenker and Bassett, 1978):

$$
\begin{aligned}
& y^{N}=w^{N} \alpha^{N}+\mu^{N} \\
& y^{M}=w^{M} \alpha^{M}+\mu^{M}
\end{aligned}
$$

where $y$ represent earnings (more correctly these are modelled as the natural log of earnings), $w$ is a vector of characteristics known to influence earnings, $\alpha$ is an estimated conformable vector of coefficient returns to these characteristics, $\mu$ an idiosyncratic error term, and the suffixes $\mathrm{N}$ and $\mathrm{M}$ denote non-movers and movers respectively. Such a regression strategy allows earnings for movers and non-movers alike to be estimated along the entire length of the earnings distribution and thus a comparison of earnings differences between them can be identified at any point $\theta$ in the earnings distribution using the decomposition framework suggested by Machado and Mata (2005). This involves drawing a finite random sample from the observed distribution to construct counterfactual earnings distributions $Q\left(\tilde{y}^{*}\right)$ that are formed on the basis of the distribution of earnings that would exist if the characteristics of non-movers were rewarded in the same way as those of movers are. This results in the following decomposition framework:

$$
Q^{\theta}\left(y^{N}\right)-Q^{\theta}\left(y^{M}\right)=\left[Q^{\theta}\left(\tilde{y}^{N}\right)-Q^{\theta}\left(\tilde{y}^{*}\right)\right]+\left[Q^{\theta}\left(\tilde{y}^{*}\right)-Q^{\theta}\left(\tilde{y}^{M}\right)\right]+\text { residual }
$$

where $Q\left(y^{N}\right)$ and $Q\left(y^{M}\right)$ are observed earnings at quantile $\theta$ for non-movers and movers respectively and $Q\left(\tilde{y}^{N}\right)$ and $Q\left(\tilde{y}^{M}\right)$ are linear predictions of earnings at quantile $\theta$ estimated from 
equations [3] and [4] respectively. Accordingly, at any comparison point $\theta$ in the earnings distributions between those who are non-movers and those who are movers, the difference in earnings may be decomposed into the components represented by equation [5]. The first term on the right hand side is the contribution of the coefficients, i.e. how the way in which the earningsdetermining characteristics contained within vector $w$ are rewarded differentially between nonmovers and movers. The second term is the contribution of the covariates that have been included in the earnings equations, i.e. the extent to which vector $w$ differs between non-movers and movers. In the decomposition set up by Machado and Mata (2005) there will also be a residual component related to simulation errors and sampling errors which would disappear with more sampling and observations and asymptotically will equal zero. ${ }^{3}$ Following an adaption of the simulation technique suggested by Melly (2007) that makes use of an infinite random sample to generate counterfactual distributions, the residual term in equation [5] will disappear. ${ }^{4}$

\section{Variables used in migration analysis}

Age: while it is generally accepted that the costs of migration are greater for older workers, the inclusion of age (and its square) is included to control for the differential incentives to move that may exist between mature students and those who have followed a more traditional (and linear) learning profile.

Gender: a dummy variable that controls for the differing likelihood of migration between males and females. While much of the migration literature has focussed upon the issue of gender in relation to tied-movements, those studies analysing gender specifically have tended to find that females are less mobile than males (see Faggian et al., 2007 inter alia).

Non-white: a dummy variable that controls for the differential incentives to move between whites and those from a non-white ethnic background. For a number of reasons, such as limited access to information, more limited resources to fund a move, or a desire to remain within or close to a local community, we would expect to find that non-whites are less mobile than their white counterparts.

Disability: a dummy variable that controls for the impact on the likelihood of moving of a reported disability. With the nature of the question asked within the data, a disability could include a physical impairment, mental health issue or a specific learning difficulty. We might expect on one hand that the reporting of a disability would inhibit mobility as support networks around the home domicile

\footnotetext{
${ }^{3}$ There would also be a specification error within this residual term induced by estimating linear quantile regression, but it is assumed that the regression model is correctly specified in this instance and hence the decomposition in equation [5] is a true decomposition based around a coefficient and characteristic effect.

${ }^{4}$ While the procedure proposed by Melly (2007) simplifies the decomposition, it makes no difference to results and conclusions drawn later. When the Machado and Mata decomposition is simulated on a finite distribution the residual element is consistently only a minor component in the decompositions across all estimated deciles.
} 
would want to be maintained. On the other hand, though, we might expect mobility to be positively related to a reported disability as students are more discerning as to the institutional support networks available to them when choosing a university.

University type and reputation: a series of dummy variables that control for differences in the quality and reputation of university attended. Four types of institution types are identified: Russell Group, the group of leading research-intensive universities; 1994 group, established research-intensive universities who at the time were not part of the Russell Group; pre-1992 universities, older universities that had traditional university status before the Further and Higher Education Act 1992; and Other, all remaining institutions including former polytechnics and new universities. In addition, a value of institutions research score from the 2001 Research Assessment Exercise is constructed to explicitly control for the intensity of research activity within institutions.

Subject of study: a series of dummy variables, based on the Joint Academic Coding System (JACS) to reflect 16 broad subject groups, to control for variation in the propensity to migrate both before and after attending university.

University choice: an indication (entered as a linear and quadratic term) of the number of universities of similar reputational standing (see above) offering the same broad course as the one studied (again see above). The expectation is that an increased number of comparable institutions to choose from in the domicile region will reduce the need or desire to move to university.

Degree class: a series of dummy variables that control for differences in human capital and/or individual ability. Six degree classifications are identified, ranging from a first, upper and lower second class, third, unclassified and other.

Unemployment spells: a series of dummy variables that control for spells of unemployment since graduation. Such spells would be indicative of a less well-matched job search. The expectation is that spells out of employment would be a driving force to undertake further job search and increase the likelihood of mobility.

Labour market characteristics: measures of population density (to measure agglomeration effects), the economic activity rate and average professional earnings (as a proxy for the potential salaries graduates can command) in the university region and the region of employment are included as an indicator of the economic environment within regions. The premise for these variables is that higher relative values provide an economic inducement to take up employment in an area, or conversely provide an incentive to leave when the economic indicators are less favourable. Additionally, given the argument that the graduate labour market is dominated by London, the distance from university to central London is also included to measure geographical isolation from this important labour market. 
Importance of degree: a series of dummy variables that control for the extent to which a degree was necessary to secure the current job. Five responses are classified, ranging from a formal requirement of the job, through being important, and helpful, to lastly being not important with a non-stated response being the final category. The expectation is that better quality students would be more likely to be employed in a job requiring a degree and more effective job search would result in a better-matched outcome between student and job. These would lead to a positive association between the importance of a degree and mobility.

Region of domicile: a series of dummy variables that control for the home domicile of students at the level of government office region.

Domicile worker: a dummy variable that signifies students work in the same government office region as they were originally domiciled in. This will differentiate between movements away from the university region that return to the home domicile region and those that do not.

\section{Variables used in earnings analysis}

Age: although age is used as a proxy for work experience in a traditional Mincer earnings function, such potential experience will not vary for a graduating cohort. Age under this scenario will account for other more general aspects of experience and seniority.

Gender: a dummy variable that controls for the differential earnings outcomes of men and women, part of which may be due to gender discrimination but will more generally reflect the unequal treatment of genders in the labour market. Such features are well-established empirical observations.

Non-white: a dummy variable that controls for differential earnings outcomes between white workers and those from a non-white ethnic background. As with the issue of gender discrimination, unequal treatment along the lines of ethnicity is a long-established empirical observation in the UK (see Blackaby et al., 2005 inter alia).

Disability: a dummy variable that controls for differential earnings outcomes between those who report a disability and those who do not. Such a control will capture potentially discriminatory behaviour, unequal treatment more generally or in this context it could also reflect productivity differences between the disabled and able-bodied workers.

Unemployment duration: the number of months (entered in linear and quadratic form) since graduation. Such controls will allow for the fact that there would be less work experience in comparison to a continuously employed individual or may send a signal of worker quality to prospective employers. The expectation would be that spells of unemployment are associated with lower earnings ceteris paribus. 
Type of contract: a dummy variable that controls for having a permanent job as opposed to a contact that is temporary or on a fixed-term basis. The expectation would be that those on permanent contracts would receive an earnings premium.

University type: a series of dummy variables that control for differences in human capital by capturing the quality and reputation of university attended, with the same four categories classified as in the mobility analysis. The expectation is that there would be a positive correlation between the quality of institution and earnings.

Subject of study: a series of dummy variables, based on the Joint Academic Coding System (JACS) to reflect 16 broad subject groups, to control for the variation in earnings outcomes across subject of graduation (see O'Leary and Sloane, 2005 inter alia).

Degree class: a series of dummy variables that control for differences in human capital and/or individual ability. The same six categories are classified as in the mobility analysis and the expectation is that there would be a positive correlation between degree class and earnings.

Region of employment: a series of dummy variables that control for the standard government office region in which graduates are employed. Given the wide variation in the regional cost of living in the UK and the concentration of graduates in London, graduate earnings and more specifically the regional premium would naturally reflect this variation (see O'Leary and Sloane, 2008).

\section{Results}

Table 1 provides a basic overview of the distribution of graduates across the standard government office regions of the UK. ${ }^{5}$ Consistent with population density patterns, there is a clustering of students being domiciled in London (13.27\%) and the South East (14.44\%) prior to attending university and much lower proportions originating from the North East (3.83\%) and Northern Ireland (4.03\%). The pattern of students attending university is not in general too dis-similar to the breakdown based on region of domicile, although it is apparent that Yorkshire and Humberside is a net importer of students while the South East is a net exporter. In terms of graduate employment, the most striking pattern is the dominance of London in the graduate labour market. Of all graduates in employment, $17.69 \%$ are to be found in this region, the largest of any individual area and a third greater than its share of domiciles. Such facts as these outlined here are well-known though but looking at these aggregate figures masks a great deal of the movement that takes place, both during the initial decision of whether to leave the domicile region to attend university and in the subsequent decision of where to take up employment after graduating. In this way, it is possible to

\footnotetext{
${ }^{5}$ All descriptive statistics reported in Table 1, and subsequently in Tables 2 and 5, use the survey weights provided by HESA to account for the non-representativeness of the survey design.
} 
categorise splits in the student population based upon movement activity both prior and subsequent to attending university as set out earlier. Such breakdowns are shown in Table 2.

Across the UK generally, $45.21 \%$ of students are classified as non-movers i.e. they attended university and are found in employment in the same region as their original domicile (Table 2, column 1). This ranges from a low of $21.46 \%$ in the Eastern region to a high of $84.69 \%$ in Scotland. Within this range, there is a clustering of regions around two points. The first is the UK average figure, as typified by the $47.85 \%$ of non-movers in the North East, $50.17 \%$ in London and $55.27 \%$ in the North West. The other is around the level of one third, with the East Midlands (29.44\%), South East (30.34\%) and South West (31.12\%) all at this mark. Also noticeable is the significant proportion of non-movers from Northern Ireland. Although not quite as high as the proportion in Scotland, nearly three quarters of Northern Ireland students (74.65\%) will not leave their domicile region to study or take up employment.

The next largest group, at both the aggregate UK level and for the majority of the individual regions, is those who move away from their domicile region to attend university but subsequently return for employment (Table 2, column 2). One quarter of students in the UK fall into this move-returner category $(24.83 \%)$. While the proportion of move-returners in most regions ranges between $21.13 \%$ (in the North West) and $35.57 \%$ (East Midlands), appreciably lower proportions are found in Wales (16.79\%), Northern Ireland (9.32\%) and Scotland (2.45\%). These later two figures in particular reflect the fact that students from these regions are the least likely to move away to study, and hence the lower proportions of move-returners does not reflect the fact that they are less likely to return if they have moved away, but rather that in Scotland and Northern Ireland students are much less likely to do anything other than remain in their home domicile.

The remaining final three columns of Table 2 show much lower proportions, with stay-leavers (column 3 ) in particular accounting for only $6.16 \%$ of students in aggregate across the UK. This ranges from a low of $1.24 \%$ in the North East to a high of $11.38 \%$ in the South West. While a greater number of students across the UK are classified as leave-stayers $(11.73 \%)$ and non-returning double movers (12.07\%), collectively these two categories only account for the same number of students as the move-returner category at the aggregate UK level. Interestingly, across these two categories Scotland and the Eastern region emerge as two contrasting cases. With only $2.97 \%$ of those domiciled in Scotland being classified as leave-stayers (Table 2, column 4) and $2.11 \%$ as nonreturning double movers (Table 2 , column 5 ), this merely reinforces the earlier sentiments that 
Scottish students have very little extra-regional mobility. For the Eastern region, though, quite the opposite is true. With $17.93 \%$ of students from this region classified as leave-stayers and $22.83 \%$ as non-returning double-movers, significantly higher than the comparable figures from other regions, the underlying story to be told for this region is one of outward student migration. Remember also that the Eastern region has already been identified as having the lowest proportion of non-movers $(21.46 \%)$ in comparison to all other regions at less than half of the UK aggregate figure.

So given these patterns identified, are there systematic differences in the likelihood of students originating from different regions migrating to attend university? What about the likelihood of subsequently moving after graduating? Is there any link between these decisions to move? Such questions are answered in the bivariate analysis that follows, the starting point of which is that initial decision of whether students move from their domicile region to another region to attend university. The results from such an analysis are shown in the left-hand side of Table 3, where the movement indicator $I_{1}$ is regressed against the set of individual characteristics and region of residence controls that were discussed in the previous section. ${ }^{6}$

The marginal effects (or influence on the probability of observing a movement) of Table 3 would concur with prior expectations. With regards to individual characteristics, increasing age (a linear component of $14.2 \%)$ and being male $(2.7 \%)$ are both associated with an increased likelihood of moving region to attend university while being from an ethnic minority background $(-13.8 \%)$ decreases the likelihood. ${ }^{7} \mathrm{~A}$ similarly negative influence is also apparent as the number of institutions in the home region increases (a linear component of $-10.4 \%)^{8}$. Such marginal effects are all statistically significant at a minimum $95 \%$ confidence level. While the marginal effect of having a

\footnotetext{
${ }^{6}$ While a number of controls are included for university quality, there are no specific controls for student quality in affecting the decision of whether to migrate away from the home domicile. A direct measure of entry qualifications is available within the DLHE data which would fulfil the requirement as a measure of student quality (i.e. UCAS tariff points on entry to university) but it is available for only a very small proportion of students. An alternative procedure would be to create a proxy for individual quality by interacting degree subject studied (16 categories) and institution type (4 categories) and include these, the reasoning being that the entry requirements for specific degree courses at universities of a similar standing would be comparable. However, this would preclude the inclusion of the degree subject dummies and the institution type dummies within the bivariate probit because of co-linearity with the interaction terms. However, when a set of interaction terms is included as a proxy for student quality and subject and institution type dummies are excluded, the results obtained are little changed qualitatively. This would fit with our prior that there is assortative matching over quality between students and universities and thus for much of the discussion that follows within the text, university quality could be substituted for student quality.

${ }^{7}$ For the discussion that follows in the text, all marginal effects are referred to as the reported figures in Table 3 (where probabilities are bounded between 0 and 1 ) multiplied by 100 to arrive at a percentage effect.

${ }^{8}$ More accurately, the control variable reflects not just the number of institutions in the respondent's domicile region but rather the number of institutions of the type (Russell Group, 1994 group, pre-192, other) attended by the respondent in his/her home region.
} 
reported disability is positive (at $4.7 \%$ ), it is only significant at the $90 \%$ confidence level. Substantial effects across degree subjects are also apparent and even though a number of the subject marginal effects are insignificantly different from the excluded baseline of degrees in Business \& administrative studies, students choosing Creative arts \& design (11.2\%) and Communication \& documentation (9.3\%) are more likely to move while those on Education (-9.6\%) and Engineering \& technology $(-9.6 \%)$ courses are less likely.

Likewise, university reputation and research quality have a role to play in influencing the decision to move to university. Firstly, the effect of a point increase in the measure of research quality is to increase the likelihood of moving by $9.6 \%$. Over and above such institutional reputation effects, the estimated effects on the type of institution variables are less clear-cut. Relative to the excluded category of Russell Group institutions, those who attended pre-1992 universities are 8.3\% less likely to move away from the domicile region, thus reinforcing the earlier finding that attending a more prestigious university (in terms of research score) increases the likelihood of movement. In contrast, the estimated marginal effects for the remaining type of institution dummies would appear initially to work against this argument, as both the Other group (30.2\%) and the 1994 group (7.0\%) report an increase in the likelihood of movement. However, there are likely to be distinct similarities between the standings of the Russell Group and 1994 group of universities and with research prestige already have been accounted for this positive finding is likely to be a spurious and residual effect. ${ }^{9}$ Indeed, when the research score is dropped from the estimating equation, there is no significant marginal effect for the 1994 group in comparison to Russell Group universities. Similarly, the magnitude of the marginal effect on the Other group of universities is reduced dramatically with the exclusion of the measure for research score, although the effect is still significantly positive. Given the heterogeneity within this latter grouping of universities, certainly much more in comparison to Russell and 1994 groups, it is not entirely obvious what the precise interpretation would be upon this marginal effect anyway.

Having controlled for these individual and university-specific characteristics, the remaining estimates in the bottom half of Table 3 show the propensity of students to leave their domicile regions measured relative to those domiciled in the East Midlands. In comparison to this constant baseline, those living in Scotland (-42.0\%) and Northern Ireland (-39.0\%) are the least likely to move away to attend university. Those domiciled in Wales $(-17.8 \%)$ and the North East $(-16.7 \%)$ are also

\footnotetext{
${ }^{9}$ Although no longer in existence, the 1994 group was formed by those research intensive universities who were not part of the Russell Group, which in itself has no formal standing. As such, the aspirational and reputations of many of the universities across these groups was likely to be similar.
} 
significantly less likely to move. At the other extreme, those from the Eastern region (15.4\%) and the South East (13.4\%) have the highest, ceteris paribus, propensity to move.

The right-hand side of Table 3 details the second aspect of the bivariate probit, in that having attended university the decision then arises of whether to move to take up employment. The effect of a student age is again significant, with older students on graduation more likely to migrate (with the marginal effect on the linear component being $10.7 \%$ ) and there is variation in the likelihood of movement dependent upon subject of study. Measured relative to degrees in Business \& administrative studies, the greatest likelihoods of movement are found in Architecture, building \& planning degrees at one extreme (12.3\%) and in Education degrees at the other (-8.2\%). As found with the first stage decision when going to university, males (2.1\%) and those with a disability (4.3\%) are more likely to move away from the region studied in while non-whites $(-5.9 \%)$ are less likely to move. ${ }^{10}$ Similarly, measures of university reputation repeat the same pattern found earlier. For one, the marginal effect on the included research quality score of $6.4 \%$ indicates a positive relationship between mobility and institutional reputation. Furthermore, the pattern on the type of institution controls similarly reveals that those graduating from pre-1992 universities are 3.8\% less likely to move away from their university region than those who attended a Russell Group institution. ${ }^{11}$

Compared with those graduating with a first class degree, students with a third class/pass degree or an unclassified award are $5.7 \%$ and $13.3 \%$ less likely to move region to gain employment respectively. Also exerting a negative influence are the controls for the importance of a degree in the current job. We might well expect that these will reflect an aspect of job quality, and by extension worker quality, where those jobs requiring a degree would be those that are commonly referred to as graduate jobs. As such, students taking up jobs where a degree was "not very important" (-4.7\%) or "not important" (-4.0\%) are significantly less likely to move. In contrast, increasing episodes of unemployment before the current job increase the probability of movement. Thus, measured relative to a student with no prior experience of unemployment since graduation, having had one unemployment spell increases the likelihood of moving to another region by $2.4 \%$. While the marginal effects associated with an increased number of unemployment spells are similarly positive, they are not significant.

\footnotetext{
${ }^{10}$ It should be noted though that both of these positive effects are right on the boundary of significance at conventional levels of acceptance. For those reporting a disability, this may partly be explained by the relatively small number of observations within the sample.

${ }^{11}$ As noted previously, the exclusion of the research quality score affects the marginal effects on the institution type. If this is done, there are significant and negative marginal effects for both the pre-1992 (-8.1\%) and the other $(-9.6 \%)$ groups. For the same arguments cited previously, it is not altogether unsurprising that the marginal effect for the 1994 group (7.6\%) remains positive.
} 
To capture differing prospects between regions of study and work, a number of indicators of economic buoyancy and opportunities are included. For those which are statistically significant, the economic activity rate $(3.8 \%)$ and the level of professional earnings $(0.1 \%)$, which may be thought of as being indicative of a graduate salary, in the region of work both act as pull factors and positively affect the decision to move from the university region. In contrast, higher professional earnings in the university region reduce the likelihood of graduates moving (-0.2\%). Also statistically significant is the estimated effect on the variable measuring the distance from university to London. London is seen as a magnet for graduates, and indeed it has already been highlighted from Table 1 that a third more graduates work in London than originate from there, but the attraction of London as a labour market for highly qualified workers diminishes with geographical distance from it.

The decision to move from region of study is also influenced by the original region of domicile and for a number of regions there are statistically discernable effects measured relative to the excluded baseline of the East Midlands. Of these, the largest marginal effects are for Scotland, Northern Ireland and Wales, where the likelihood of movement is reduced by $32.1 \%, 15.6 \%$ and $13.5 \%$ respectively. This reinforces the earlier observation that for these three domicile regions there was also a significantly lower likelihood of students moving away to study at university and suggests that for whatever reason there is an increased attachment of students to their home regions that substantially reduces their mobility. Interestingly, those originating from the North East are $13.7 \%$ more likely to move for work and this stands as an outlier to all of the other regions. Thus, even though students from the North East were significantly less likely to move away to university, this lack of mobility does not extend to the subsequent migration decision to employment. ${ }^{12}$

Finally, the estimate of $\rho$ in the bivariate probit, the term describing the correlation between the unobservables in the move-to-university and the move-to-work equations, is highly significant and positive. Not only does this reaffirm the veracity of modelling the two-stage movement decision in the way that we have, but it also suggests that those individual traits that influence whether to move, such as drive, ambition, personality etc., but are not observed in the data, will influence the decision to move both pre- and post-university in the same way. Thus, while the previous investigation has shown that there is graduate mobility, and London in particular is a dominant

\footnotetext{
${ }^{12}$ These marginal effects by region of domicile are not influenced by workers returning to their home domicile region as this potential movement is controlled for by a domicile worker dummy. The fact that the marginal effect on this variable is positive (at $4.2 \%$ ) would imply that those who do move away from their university region are more likely to return to their home domicile, ceteris paribus, than move to another region. Note, though, that the effects associated with the original domicile region are invariant to the inclusion of the domicile worker control.
} 
destination for degree-qualified workers, there nevertheless exists substantial attachment to the domicile region. This extends not only to students choosing to study at a university in their home domicile, but also to returning subsequently to find employment. It should be remembered, though, that those factors that affect mobility are both the characteristics that have been included within the bivariate setting used here and underlying personality traits. The fact that such observed and unobserved characteristics influence mobility is important at the level of the individual because mobility affects the earnings that graduates are able to command. We turn to this in the next part.

Quantile regressions have been run between annual salary and a host of income determining characteristics and factors and while it would be impossible to present results across the entirety of the earnings distribution and for all movement categories, estimates at the lower quartile, median and upper quartile for a pooling of all workers are given in Table 4 as an illustration. ${ }^{13}$ While it is impractical to give a detailed account of the individual estimates, they were nonetheless consistently well-defined and conformed to a familiar pattern: earnings increase with age (though at a decreasing rate), and are higher for males and for those on a permanent contract as opposed to those employed on a fixed term/temporary basis; earnings are lower for those of an ethnic background other than white and decrease with months spent unemployed since graduation; there are large regional variations in earnings, with the highest returns being found in the South East and London; large earnings differentials are evident across degree subjects, with Creative arts \& design and Linguistics, languages \& literature conferring some of the lowest returns; and finally, lower degree classifications substantially reduce earnings. These were general findings that were evident over all of the quartile ranges. ${ }^{14}$

An important determinant of earnings is occupational attainment but these have not been included as we do not want to conflate this issue with earnings levels (or more specifically an earnings premium). It is apparent, though, that those who are mobile, or have chosen to be mobile, are more likely to be in a better, and by extension higher-paying, job. This is shown in Table 5. For those who move neither to university nor for subsequent employment i.e non-movers (Table 5 , column 1 ), a combined $79.13 \%$ of jobs are in the highest three occupational categories (Managers \& senior officials, Professional and Associate professional \& technical). Compare this outcome to that for

\footnotetext{
${ }^{13}$ The choice of variables entering the model was largely motivated by theoretical considerations and the existing literature and a list of these is given in the previous section. A full set of results by decile and across movement categories is available from the authors on request.

${ }^{14}$ Interestingly, there was no definitive earnings effect associated with institution type. The only situation where there was a significant premium to degree class was for 'other' awards relative to first class degrees at the lower and upper quartile. In such instances, there was an earnings disadvantage associated with not having the higher classification.
} 
those students who move to attend university and move onwards afterwards without returning to the home domiciles (Table 5, column 5). For such individuals, the comparable proportion is markedly higher at $83.17 \%$. Between these two extremes of moving are those who either move just once or else do move twice but return to their home domicile to find work and the comparable occupational distributions for these groups are between the two figures reported (Table 5, columns 2-4). Thus, it appears that much of the occupational benefit derives from a wider-ranging job search area after graduation rather than the movement away to university in the first instance. The same evidence is apparent in the bottom half of Table 5 where two measures of graduate jobs are given. The first is a measure based directly on occupational classification and this clearly shows that non-movers (76.45\%) and those who return to their home domicile to work (74.64\%) are less likely to be in a graduate occupation than non-returning double-movers (81.20\%). ${ }^{15}$ Similarly, those who report that a degree was a requirement for their job is much lower for non-movers $(29.89 \%)$ than for those categorised as non-returning double-movers $(38.11 \%)$ or stay leavers $(51.45 \%)$. Indeed, it is the greater job search implicit between the stay-leavers and the move-returner and leave-stayer groups that differentiates these three movement categories. All three involve at least one episode of movement and yet the proportion in graduate jobs for the stay-leaver group (at $51.45 \%$ ) is appreciably higher than for the other two who exhibit less mobility in their movement away from university (at $23.20 \%$ for move-returners and $33.39 \%$ for leave-stayers).

Given the underlying quantile regressions run at each decile for the five groups of graduate movers identified, Table 6 presents the results of the decomposition exercise for four categories of graduates relative to those who neither moved to university nor subsequently moved to work. For what might be thought of as being a fairly homogeneous group of workers once degree outcomes (in terms of quality and subject of study) and region of employment have been accounted for, under such a scenario there would not be an expectation of any systematic differences in earnings between workers. This palpably is not the case, although in the first comparison in Table 6, between non-movers and move-returners, there does in the most part appear to be an insignificant unexplained component between graduates. Where this is not true is in the upper and lower reaches of the earnings distribution, where there is a significant earnings premium to move returners at the first decile (of 0.093 log points), the second decile ( 0.035 log points) and at the ninth decile (0.029 log points). At all other points of the earnings distribution, the small earnings advantage of non-movers is virtually entirely explained by composition differences between the two

\footnotetext{
${ }^{15}$ Specifically, 5-digit SOC 2003 codes are used that are consistent with the classification of Davies, Elias and Ellison (2003)
} 
sets of graduates. This can be clearly seen in panel (a) of Figure 1, where the $95 \%$ confidence interval of the point estimates overlaps zero log points for all but the tails of the earnings distribution.

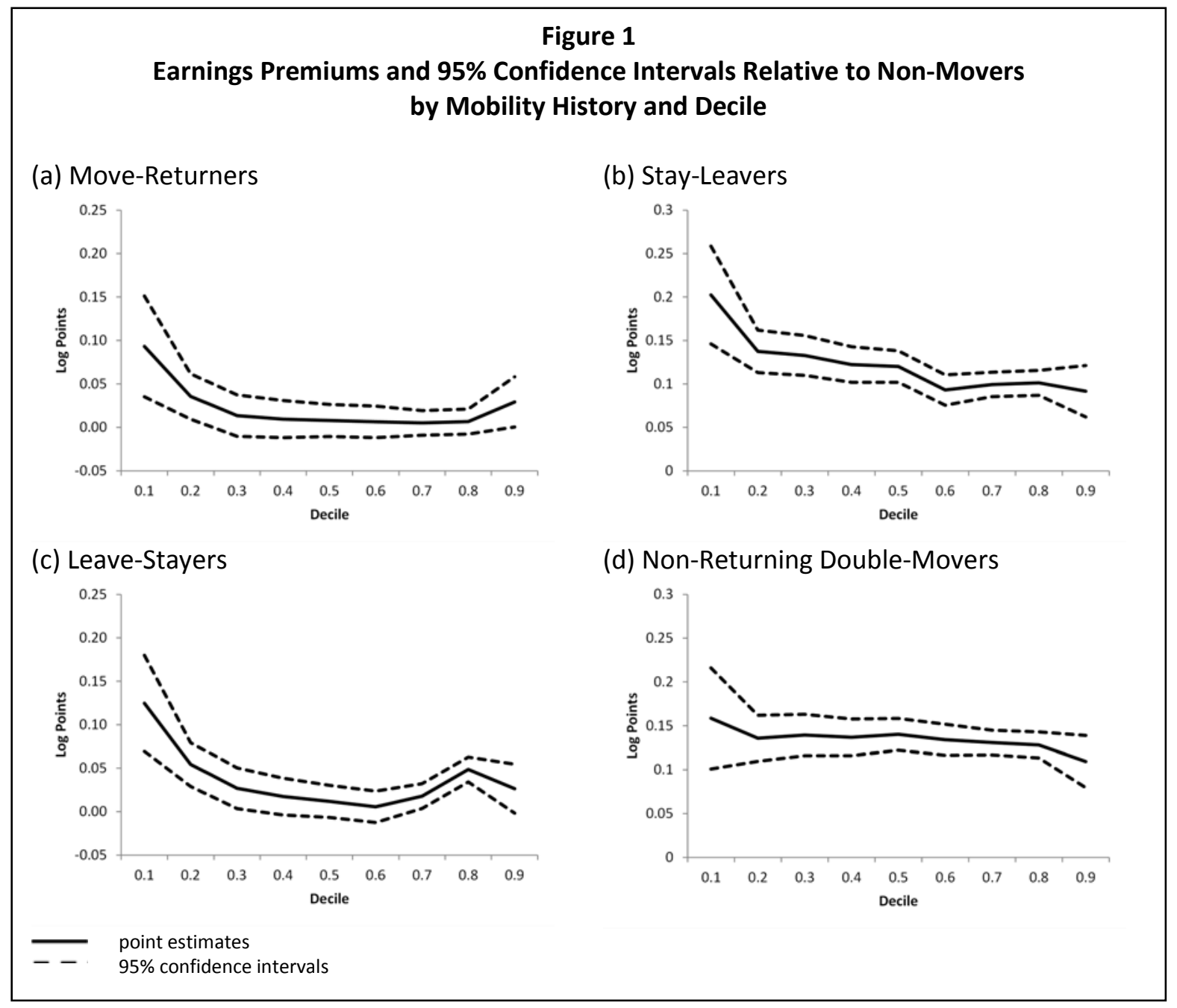

For the comparison of non-movers against stay-leavers, there is a substantial unexplained earnings component observed at all points across the earnings distribution. Thus, the appreciably higher earnings of stay-leavers observed over all deciles are only minimally explained by characteristic differences and instead the dominant component in the decomposition is the unexplained (coefficient) component. This component also declines in magnitude as earnings increase, falling from 0.202 log points at the first decile, through 0.120 log points at median earnings, to $0.092 \log$ points at the ninth decile (see panel (b) of Figure 1 also). Meanwhile, for the non-returning doublemovers a similar pattern is exhibited as for the stay-leavers. Those who move in this way have higher observed earnings than the non-movers and the dominant factor in the decomposition at each and every decile is the unexplained component. However, while the magnitude of the point estimates of 
the unexplained component declines along the earnings distribution, falling from a high of $0.158 \mathrm{log}$ points at the first decile to a low of 0.109 log points at the ninth, panel (d) of Figure 1 shows more readily that there is in fact little variation in the size of the premium over most of the earnings distribution. Outside of the first and last deciles, point estimates are stable around the level of 0.13$0.14 \log$ points.

The comparison of stay-leavers with non-movers produces results that are somewhere between the three sets already discussed. The raw earnings differentials at each of the deciles are generally quite modest outside of the top and bottom deciles and characteristic differences account for an increasingly larger part of these differentials as we move along the earnings distribution. A positive earnings premium is enjoyed by stay-leavers over non-movers in the bottom three and top three deciles (see also Figure 1 panel (c)) and with the exception of at the very top decile, the premiums are between those found for move-returners as a lower bound and non-returning double-movers as an upper bound. In general, though, these premiums are relatively modest.

\section{Conclusions}

The adoption of a bivariate framework when modelling the dual mobility decision of moving to and from university highlights the importance of the inter-relationship between these two decisions with those unobservable characteristic traits, which we could think of as encapsulating attributes such as motivation, drive and ambition, positively affecting both the decision to leave the home domicile and also the decision to move from the comfort of university or home region when entering the labour market. In common with existing evidence, it is found that males tend to be more mobile than females and non-whites tend to be less mobile than their white majority counterparts. It is also found that the quality of institution and quality of students themselves have a significant influence on movement both pre- and post-graduation, with more able students and those attending more prestigious universities more likely to move. There are also distinct mobility patterns evident based upon region of domicile, with Northern Irish, Scottish and Welsh students far less mobile than comparable students from the majority of English regions.

Such a lack of mobility is important at the individual level for students themselves as those who are more mobile enjoy an earnings premium over those who are less so. Students who remain in their home domicile region fare the least well and never experience an earnings advantage over their more mobile contemporaries at any point of the earnings distribution. The greatest advantage is for those who move region not only to attend university but also subsequently move away from 
university without returning to their home domicile region. For such students, substantial earnings premiums in the range of $11-15 \%$ are found relative to non-movers. While premiums are also evident for other aspects of mobility, the crucial distinction is between those who may in some way have constrained their location of job search: for those who do move to university but subsequently return to the home domicile, no earnings premium is apparent over most parts of the earnings distribution; for those who do exhibit mobility over university choice but remain in this region for employment, much more modest premiums, certainly less than the $11-15 \%$ range cited previously, are estimated; and indeed, for those who are regionally immobile in the choice of university but who subsequently do move to take up employment, comparable premiums in the range of $10-14 \%$ are earned for all but the very highest and very lowest decile workers.

Such findings will also have important considerations from a policy perspective and there will inevitably be a tension between regional prosperity for donor regions and the financial returns available for students themselves. Regions will have vested interests in retaining, or perhaps even recruiting, highly qualified workers and given the current funding regimes in Scotland and Wales as examples that see the tuition fees of domestic students subsidised, there are obvious financial implications for regions that find themselves as net exporters of student talent. Against this backdrop, the financial rewards available to students are higher for those who do not show regional loyalty. Even though there is the suggestion that such returns may be driven by traits such as motivation and drive and not mobility itself, there is compelling evidence to suggest that it is more effective job search which is behind the superior labour market outcomes. Naturally there is likely to be a correlation between motivation, drive and mobility, but it is ultimately the wider-ranging job matching process that drives higher earnings and not underlying personal attributes, whether they be observed or unobserved. 


\section{References}

Abreu M., Faggion A. and McCann P., Migration and Inter-Industry Mobility of UK Graduates, Journal of Economic Geography, 2014 (forthcoming), doi 10.1093/jeg/1bt043.

Abreu M., Kitson M. and Wales P., The Movement of Talent: Migration Patterns among UK Graduates and Implications for UK Economic Disparities, UK Innovation Research Centre, Imperial College and University of Cambridge, 2008.

Becker G., Human Capital; A Theoretical and Empirical Analysis, Columbia University Press, New York, 1964.

Blackaby, D., Leslie, D., Murphy, P. and O'Leary, N., Born in Britain: How are Native Ethnic Minorities Faring in the British Labour Market, Economics Letters, 2005, 88, 370-375.

Bristow G., Pill M., Davies R. and Drinkwater S., Welsh Graduate Mobility, SKOPE/WISERD Report, Cardiff University, 2011.

Chevalier A., Subject Choice and Earnings of UK Graduates, Economics of Education Review, 30(6), 2011, 1187-1201.

DaVanzo J., Differences between Return and Non Return Migration: An Econometric Analysis, International Migration Review, 10, Spring, 1976, 13-27.

DaVanzo J., Repeat Migration in the United States: Who Moves Back and Who Moves On, Review of Economics and Statistics, 65(4), 1983, 552-559.

Davies R., Elias P. and Ellison R., Standard Occupational Classification for the Destinations of Leavers from Higher Education Institutions: SOC (DLHE), HESA, 2003.

Denzler S. and Wolter S., Too Far to Go? Does Distance Determine Study Choices? IZA Discussion Paper No. 5712, May, 2011.

de Grip, A., Bosma, H., Willems, D. and van Boxtel, M., Job Worker Mismatch and Cognitive Decline, Oxford Economic Papers, 60(2), 2008, 237-253.

Faggion A., McCann P. and Sheppard S., Human Capital, Higher Education and Graduate Migration: An Analysis of Scottish and Welsh Students, Urban Studies, 44, 2007, 2511-2528.

Faggion A. and McCann P., Human Capital, Graduate Migration and Innovation in British Regions, Cambridge Journal of Economics, 33, 2009,317-333.

Hoare A. and Corver M., The Regional Geography of New Young Graduate Labour in the UK, Regional Studies, 44(4), 2010, 477-494.

Koenker R. and Bassett G., Regression Quantiles, Econometrica, 46(1),1978,33-50.

Machado J. and Mata J., Counterfactual Decompositions of Changes in Wage Distributions Using Quantile Regressions, Journal of Applied Econometrics, 20(4), 2005, 445-465. 
Melly B., Rqdeco: a Stata Module to Decompose Differences in Distribution, mimeo, University of St Gallen, 2007.

Mosca I. and Wright R., National and International Migration Flows, Population Trends, 141, 2010, 36-53.

Naylor R., Smith J. and McKnight A., Determinants of Occupational Earnings: Evidence for the 1993 UK University Graduate Population from the University Student Record, mimeo, University of Warwick, 1998.

O'Leary N. and Sloane P., The Return to a University Education in Great Britain, National Institute Economic Review, 193 July, 2005, 75-89.

O'Leary N. and Sloane P., Rates of Return to Degrees across British Regions, Regional Studies, 42(2), 2008, 199-213.

Osborne R., Cormack R. and Miller R. (eds), Education and Policy in Northern Ireland, Policy Research Institute, Belfast, 1987.

Sjaastad L., The Costs and Returns of Human Migration, Journal of Political Economy,70, 1962, 80-93.

Walker I. and Zhu Y., Differences by Degree: Evidence of the Net Financial Rates of Return to Undergraduate Study for England and Wales, Economics of Education Review, 30(6), 2011, 177-1186.

Winters J., Differences in Employment Outcomes for College Town Stayers and Leavers, IZA Journal of Migration, 1-11, 2012.

Wright J., Cutting the Apron Strings? The Clustering of Young Graduates and the Role of the Public Sector, A Cities 2020 Research Paper, The Work Foundation, February, 2011. 
Table 1

Distribution of UK Students and Working Graduates by Government Office Region (\%s)

\begin{tabular}{|l|r|r|r|}
\cline { 2 - 4 } \multicolumn{1}{c|}{} & \multicolumn{1}{c|}{ Domicile } & Institution & Employment \\
\hline North East & 3.83 & 4.34 & 3.58 \\
\hline North West & 11.84 & 12.61 & 11.56 \\
\hline Yorkshire \& Humberside & 7.14 & 12.49 & 8.32 \\
\hline East Midlands & 6.75 & 6.75 & 5.82 \\
\hline West Midlands & 8.09 & 7.74 & 6.52 \\
\hline Eastern & 9.09 & 5.86 & 6.47 \\
\hline London & 13.27 & 13.23 & 17.69 \\
\hline South East & 14.44 & 11.07 & 12.43 \\
\hline South West & 8.72 & 8.23 & 7.00 \\
\hline Wales & 4.62 & 5.39 & 4.72 \\
\hline Scotland & 8.20 & 9.06 & 8.15 \\
\hline Northern Ireland & 4.03 & 3.24 & 3.38 \\
\hline Outside UK & 0.00 & 0.00 & 4.36 \\
\hline Sample size & 14,153 & 14,534 & 10,213 \\
\hline
\end{tabular}

Note: all figures are weighted using finalwt. 
Table 2

Graduate Mobility Patterns by Government Office Region of Domicile (\%s)

\begin{tabular}{|l|r|r|r|r|r|}
\hline & \multicolumn{1}{|c|}{$\begin{array}{c}\text { Non- } \\
\text { Movers }\end{array}$} & $\begin{array}{c}\text { Move- } \\
\text { Returners }\end{array}$ & $\begin{array}{c}\text { Stay- } \\
\text { Leavers }\end{array}$ & $\begin{array}{c}\text { Leave- } \\
\text { Stayers }\end{array}$ & $\begin{array}{c}\text { Non-Returning } \\
\text { Double-Movers }\end{array}$ \\
\hline North East & 47.85 & 29.12 & 1.24 & 7.12 & 14.67 \\
\hline North West & 55.27 & 21.13 & 4.36 & 9.75 & 9.48 \\
\hline Yorkshire \& Humberside & 48.38 & 24.49 & 9.78 & 6.50 & 10.86 \\
\hline East Midlands & 29.44 & 35.57 & 3.02 & 19.31 & 12.67 \\
\hline West Midlands & 38.40 & 32.60 & 5.29 & 12.16 & 11.56 \\
\hline Eastern & 21.46 & 33.49 & 4.29 & 17.93 & 22.83 \\
\hline London & 50.17 & 27.83 & 7.12 & 7.16 & 7.71 \\
\hline South East & 30.34 & 29.49 & 6.03 & 15.34 & 18.80 \\
\hline South West & 31.12 & 25.95 & 11.38 & 17.75 & 13.80 \\
\hline Wales & 54.17 & 16.79 & 4.91 & 13.92 & 10.21 \\
\hline Scotland & 84.69 & 2.45 & 7.77 & 2.97 & 2.11 \\
\hline Northern Ireland & 74.65 & 9.32 & 4.39 & 7.34 & 4.30 \\
\hline Aggregate UK & $\mathbf{4 5 . 2 1}$ & $\mathbf{2 4 . 8 3}$ & $\mathbf{6 . 1 6}$ & $\mathbf{1 1 . 7 3}$ & $\mathbf{1 2 . 0 7}$ \\
\hline
\end{tabular}

Note: all figures are weighted using finalwt. 
Table 3

Marginal Effects of Joint Decision to Move from Home Domicile to University and from University to Work

\begin{tabular}{|c|c|c|c|c|}
\hline & \multicolumn{2}{|c|}{$\begin{array}{l}\text { Move to University } \\
\qquad\left(I_{1}\right)\end{array}$} & \multicolumn{2}{|c|}{$\begin{array}{c}\text { Move to Work } \\
\left(I_{2}\right)\end{array}$} \\
\hline & ME & Z-stat & $\mathrm{ME}$ & Z-stat \\
\hline Age at entry & 0.142 & 3.00 & & \\
\hline Age at entry squared & -0.004 & -3.65 & & \\
\hline Age & & & 0.107 & 2.08 \\
\hline Age squared & & & -0.003 & -2.55 \\
\hline Male & 0.027 & 1.98 & 0.021 & 1.65 \\
\hline Non-white & -0.138 & -8.70 & -0.059 & -3.79 \\
\hline Disability & 0.047 & 1.72 & 0.043 & 1.63 \\
\hline University choices & -0.104 & -14.29 & & \\
\hline University choices squared & 0.004 & 11.18 & & \\
\hline University research quality & 0.096 & 9.52 & 0.064 & 6.59 \\
\hline $\begin{array}{l}\text { Institution type } \\
\text { Russell Group }\end{array}$ & (E) & (E) & (E) & (E) \\
\hline 1994 group & 0.070 & 2.69 & 0.101 & 3.97 \\
\hline Pre-1992 & -0.083 & -3.93 & -0.038 & -1.89 \\
\hline Other & 0.302 & 9.67 & 0.049 & 1.79 \\
\hline Degree subject & & & & \\
\hline Medicine \& dentistry & 0.002 & 0.06 & -0.051 & -1.22 \\
\hline Subjects allied to medicine & -0.031 & -1.21 & 0.009 & 0.35 \\
\hline Biological, veterinary \& agricultural & 0.002 & 0.07 & 0.081 & 2.89 \\
\hline Physical sciences & 0.019 & 0.50 & 0.054 & 1.48 \\
\hline Mathematics \& computer science & -0.060 & -1.76 & -0.004 & -0.13 \\
\hline Engineering \& technology & -0.096 & -2.89 & 0.052 & 1.46 \\
\hline Architecture, building \& planning & -0.058 & -1.13 & 0.123 & 2.41 \\
\hline Social studies & -0.043 & -1.36 & -0.019 & -0.62 \\
\hline Law & -0.087 & -1.95 & 0.016 & 0.35 \\
\hline Business \& administrative studies & (E) & (E) & $(E)$ & $(\mathrm{E})$ \\
\hline Communication \& documentation & 0.093 & 2.19 & 0.060 & 1.46 \\
\hline Linguistics, languages \& literature & 0.059 & 1.73 & 0.059 & 1.81 \\
\hline History \& philosophy & -0.012 & -0.26 & 0.021 & 0.47 \\
\hline Creative arts $\&$ design & 0.112 & 3.59 & 0.036 & 1.28 \\
\hline Education & -0.096 & -3.44 & -0.082 & -3.14 \\
\hline Combined & 0.029 & 1.33 & 0.013 & 0.64 \\
\hline Degree class & & & & \\
\hline First & & & $(E)$ & $(E)$ \\
\hline Upper second & & & 0.002 & 0.11 \\
\hline Lower second/unclassified second & & & -0.020 & -1.07 \\
\hline Third/pass & & & -0.057 & -2.14 \\
\hline Unclassified & & & -0.133 & -3.57 \\
\hline Other & & & 0.032 & 0.92 \\
\hline Number of unemployment spells & & & & \\
\hline 0 & & & $(\mathrm{E})$ & $(E)$ \\
\hline 1 & & & 0.024 & 1.90 \\
\hline 2 & & & 0.011 & 0.50 \\
\hline 3 & & & 0.054 & 1.41 \\
\hline
\end{tabular}




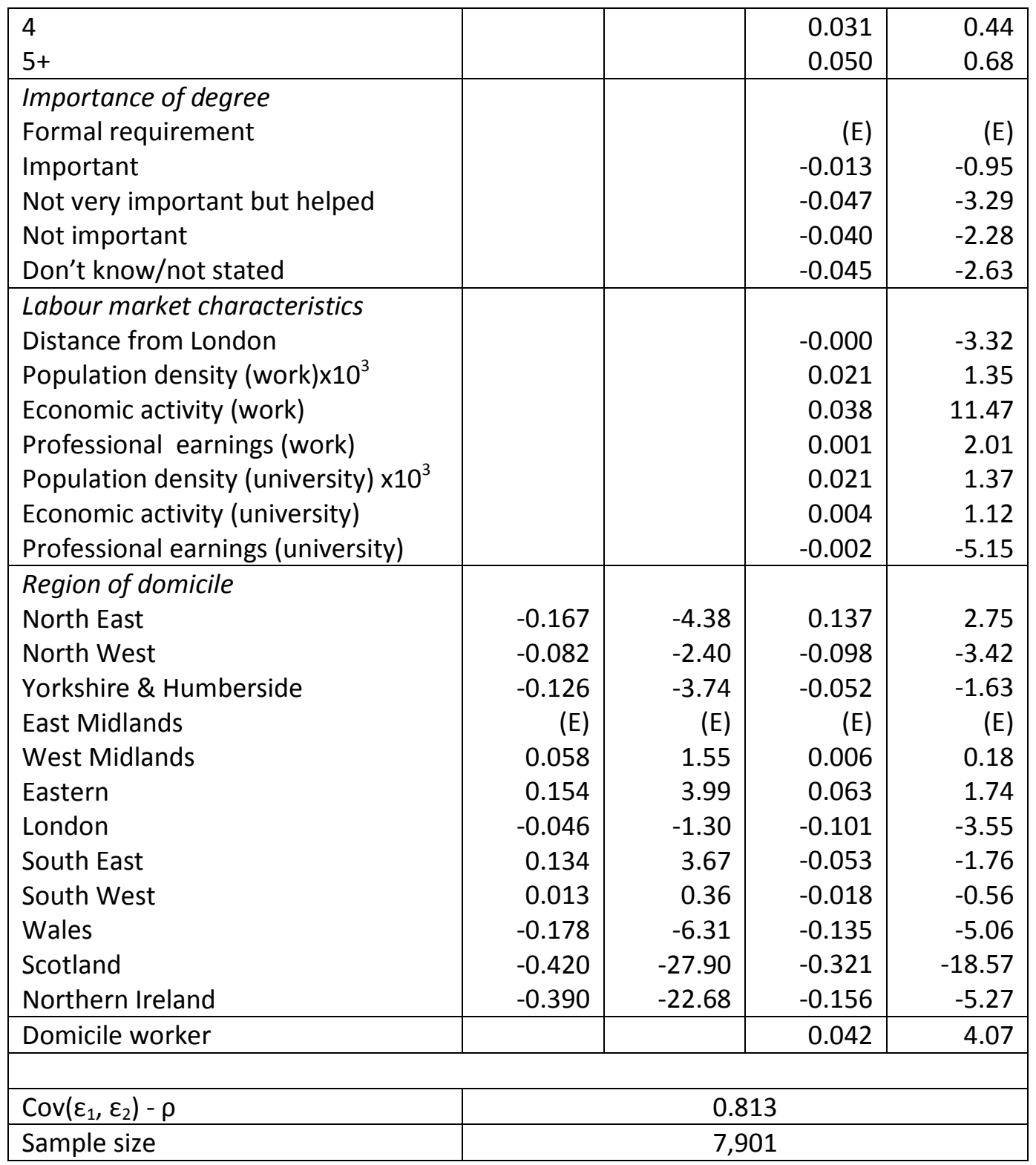

Note: (E) denotes and excluded reference category; in the likelihood function atan $\rho$ is estimated with a coefficient value of 1.135 and a standard error of 0.029 (z-score 38.61); likelihood ratio test that $\rho=0\left(\chi_{(1)}^{2}=2019.13\right)$ is easily rejected. 
Table 4

Wage Equating Estimates by Quartile

\begin{tabular}{|c|c|c|c|c|c|c|}
\hline & \multicolumn{2}{|c|}{0.25} & \multicolumn{2}{|c|}{0.5} & \multicolumn{2}{|c|}{0.75} \\
\hline & Coef & t-stat & Coef & t-stat & Coef & t-stat \\
\hline Age & 0.177 & 2.89 & 0.128 & 3.05 & 0.061 & 1.51 \\
\hline Age squared & -0.003 & -2.41 & -0.002 & -2.45 & -0.001 & -0.79 \\
\hline Male & 0.017 & 0.98 & 0.035 & 2.92 & 0.049 & 4.32 \\
\hline Non-white & -0.054 & -2.69 & -0.037 & -2.71 & -0.020 & -1.48 \\
\hline Disability & -0.011 & -0.32 & 0.008 & 0.33 & -0.010 & -0.43 \\
\hline Months unemployed & -0.014 & -2.97 & -0.017 & -4.96 & -0.022 & -6.84 \\
\hline Months unemployed squared & 0.000 & 0.71 & 0.000 & 0.55 & 0.001 & 4.89 \\
\hline Permanent contract & 0.100 & 6.01 & 0.075 & 6.60 & 0.058 & 5.30 \\
\hline Institution type & & & & & & \\
\hline Russell Group & $(E)$ & (E) & $(E)$ & (E) & (E) & $(E)$ \\
\hline 1994 group & -0.011 & -0.36 & 0.016 & 0.74 & -0.001 & -0.05 \\
\hline Pre-1992 & -0.027 & -1.05 & 0.019 & 1.08 & -0.014 & -0.82 \\
\hline Other & -0.037 & -1.75 & -0.002 & -0.17 & -0.028 & -2.04 \\
\hline Degree class & & & & & & \\
\hline First & $(E)$ & $(E)$ & $(E)$ & $(E)$ & $(E)$ & $(E)$ \\
\hline Upper second & -0.039 & -1.44 & -0.021 & -1.12 & -0.042 & -2.37 \\
\hline Lower second/unclassified second & -0.080 & -2.77 & -0.074 & -3.76 & -0.089 & -4.73 \\
\hline Third/pass & -0.118 & -2.49 & -0.126 & -3.90 & -0.127 & -4.12 \\
\hline Unclassified & 0.052 & 0.76 & 0.092 & 1.94 & 0.049 & 1.07 \\
\hline Other & -0.005 & -0.09 & 0.020 & 0.56 & -0.014 & -0.42 \\
\hline Degree subject & & & & & & \\
\hline Medicine \& dentistry & (E) & (E) & (E) & $(E)$ & (E) & (E) \\
\hline Subjects allied to medicine & -0.623 & -10.03 & -0.553 & -13.04 & -0.507 & -12.49 \\
\hline Biological, veterinary \& agricultural & -0.843 & -13.04 & -0.735 & -16.62 & -0.657 & -15.54 \\
\hline Physical sciences & -0.834 & -11.50 & -0.720 & -14.53 & -0.633 & -13.35 \\
\hline Mathematics \& computer science & -0.755 & -10.73 & -0.631 & -13.12 & -0.507 & -11.02 \\
\hline Engineering \& technology & -0.539 & -7.88 & -0.475 & -10.18 & -0.455 & -10.18 \\
\hline Architecture, building \& planning & -0.608 & -7.28 & -0.583 & -10.23 & -0.525 & -9.63 \\
\hline Social studies & -0.708 & -10.29 & -0.645 & -13.74 & -0.567 & -12.60 \\
\hline Law & -0.809 & -9.30 & -0.707 & -11.91 & -0.636 & -11.18 \\
\hline Business \& administrative studies & -0.728 & -11.47 & -0.666 & -15.38 & -0.580 & -13.99 \\
\hline Communication \& documentation & -0.871 & -10.69 & -0.739 & -13.29 & -0.693 & -13.01 \\
\hline Linguistics, languages \& literature & -0.814 & -12.03 & -0.740 & -16.00 & -0.617 & -13.95 \\
\hline History \& philosophy & -0.808 & -9.45 & -0.753 & -12.89 & -0.662 & -11.84 \\
\hline Creative arts \& design & -0.932 & -13.12 & -0.820 & -16.89 & -0.743 & -15.99 \\
\hline Education & -0.425 & -6.35 & -0.449 & -9.83 & -0.452 & -10.34 \\
\hline Combined & -0.731 & -11.83 & -0.630 & -14.94 & -0.542 & -13.43 \\
\hline Region of employment & & & & & & \\
\hline North East & (E) & (E) & (E) & (E) & (E) & (E) \\
\hline North West & -0.021 & -0.38 & -0.054 & -1.42 & -0.053 & -1.47 \\
\hline Yorkshire \& Humberside & 0.003 & 0.05 & -0.030 & -0.77 & -0.031 & -0.84 \\
\hline East Midlands & 0.041 & 0.69 & 0.011 & 0.27 & -0.034 & -0.88 \\
\hline West Midlands & -0.036 & -0.62 & -0.024 & -0.63 & -0.037 & -0.98 \\
\hline Eastern & 0.025 & 0.44 & 0.022 & 0.57 & -0.000 & -0.01 \\
\hline London & 0.150 & 2.93 & 0.127 & 3.62 & 0.131 & 3.92 \\
\hline South East & 0.085 & 1.60 & 0.086 & 2.37 & 0.047 & 1.36 \\
\hline
\end{tabular}




\begin{tabular}{|l|r|r|r|r|r|r|}
\hline South West & -0.029 & -0.51 & -0.049 & -1.25 & -0.082 & -2.17 \\
Wales/Other & -0.140 & -2.66 & -0.145 & -4.03 & -0.094 & -2.71 \\
Scotland/Northern Ireland & -0.085 & -1.67 & -0.096 & -2.77 & -0.064 & -1.94 \\
\hline Constant & 7.801 & 10.58 & 8.510 & 16.90 & 9.39 & 19.49 \\
\hline Sample size & \multicolumn{5}{|c|}{3,717} \\
\hline
\end{tabular}

Note: (E) denotes and excluded reference category. 
Table 5

Occupational Attainment (\%) by Movement Category

\begin{tabular}{|l|r|r|r|r|r|}
\cline { 2 - 5 } \multicolumn{1}{c|}{} & \multicolumn{1}{c|}{$\begin{array}{c}\text { Non- } \\
\text { Movers }\end{array}$} & $\begin{array}{c}\text { Move- } \\
\text { Returners }\end{array}$ & $\begin{array}{c}\text { Stay- } \\
\text { Leavers }\end{array}$ & $\begin{array}{c}\text { Leave- } \\
\text { Stayers }\end{array}$ & $\begin{array}{c}\text { Non-Returning } \\
\text { Double-Movers }\end{array}$ \\
\hline Occupation & & & & & \\
Managers \& senior officials & 11.88 & 12.68 & 16.87 & 12.99 & 17.07 \\
Professional & 32.70 & 32.12 & 32.66 & 42.53 & 35.13 \\
Associate professional \& technical & 34.55 & 32.00 & 29.49 & 27.21 & 30.97 \\
Administrative \& secretarial & 10.21 & 14.02 & 10.58 & 7.99 & 9.39 \\
Skilled trades & 0.79 & 1.20 & 0.62 & 1.19 & 0.71 \\
Personal services & 2.69 & 3.00 & 2.67 & 1.67 & 2.52 \\
Sales \& customer services & 4.24 & 3.41 & 5.00 & 3.01 & 2.30 \\
Process, plant \& machine operatives & 0.96 & 0.42 & 1.30 & 1.01 & 0.48 \\
Elementary & 1.98 & 1.17 & 0.81 & 2.41 & 1.43 \\
\hline Graduate occupation & 76.45 & 74.64 & 76.80 & 80.95 & 81.20 \\
\hline Degree required & & & & & \\
Required & 29.89 & 23.20 & 51.45 & 33.39 & 38.11 \\
Expected & 6.39 & 8.07 & 9.68 & 12.80 & 14.04 \\
Advantage & 17.92 & 22.84 & 21.43 & 18.12 & 26.31 \\
No & 45.80 & 45.90 & 17.44 & 35.69 & 21.55 \\
\hline
\end{tabular}

Note: all figures are weighted using finalwt. 
Table 6

Earnings Decomposition Results by Decile Relative to Non-Movers

\begin{tabular}{|c|c|c|c|c|c|c|c|c|c|c|}
\hline & & & & & & & & & \\
\hline & & 0.1 & 0.2 & 0.3 & 0.4 & 0.5 & 0.6 & 0.7 & 0.8 & 0.9 \\
\hline \multirow{3}{*}{ 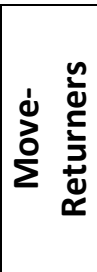 } & $\begin{array}{l}\text { Earnings } \\
\text { Differential }\end{array}$ & $\begin{array}{l}0.032 \\
(1.08)\end{array}$ & $\begin{array}{l}-0.003 \\
(-0.16)\end{array}$ & $\begin{array}{l}-0.026 \\
(-1.90)\end{array}$ & $\begin{array}{l}-0.036 \\
(-2.51)\end{array}$ & $\begin{array}{l}-0.042 \\
(-2.95)\end{array}$ & $\begin{array}{l}-0.044 \\
(-3.39)\end{array}$ & $\begin{array}{l}-0.037 \\
(-3.41)\end{array}$ & $\begin{array}{l}-0.026 \\
(-2.28)\end{array}$ & $\begin{array}{l}-0.037 \\
(-2.34)\end{array}$ \\
\hline & Characteristics & $\begin{array}{l}-0.061 \\
(-1.39)\end{array}$ & $\begin{array}{l}-0.038 \\
(-1.69)\end{array}$ & $\begin{array}{l}-0.039 \\
(-2.41) \\
\end{array}$ & $\begin{array}{l}-0.046 \\
(-3.21) \\
\end{array}$ & $\begin{array}{l}-0.050 \\
(-3.80) \\
\end{array}$ & $\begin{array}{l}-0.050 \\
(-4.17)\end{array}$ & $\begin{array}{l}-0.042 \\
(-3.93) \\
\end{array}$ & $\begin{array}{l}-0.033 \\
(-3.35) \\
\end{array}$ & $\begin{array}{l}-0.066 \\
(-4.72) \\
\end{array}$ \\
\hline & Coefficients & $\begin{array}{l}0.093 \\
(3.15)\end{array}$ & $\begin{array}{l}0.035 \\
(2.66)\end{array}$ & $\begin{array}{l}0.013 \\
(1.10)\end{array}$ & $\begin{array}{l}0.009 \\
(0.87)\end{array}$ & $\begin{array}{l}0.008 \\
(0.84)\end{array}$ & $\begin{array}{l}0.006 \\
(0.68)\end{array}$ & $\begin{array}{l}0.005 \\
(0.70)\end{array}$ & $\begin{array}{l}0.007 \\
(0.89)\end{array}$ & $\begin{array}{l}0.029 \\
(1.98)\end{array}$ \\
\hline \multirow{3}{*}{ 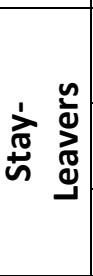 } & $\begin{array}{l}\text { Earnings } \\
\text { Differential }\end{array}$ & $\begin{array}{l}0.224 \\
(4.33) \\
\end{array}$ & $\begin{array}{l}0.164 \\
(4.48) \\
\end{array}$ & $\begin{array}{l}0.157 \\
(5.14) \\
\end{array}$ & $\begin{array}{l}0.146 \\
(5.86) \\
\end{array}$ & $\begin{array}{l}0.142 \\
(6.17) \\
\end{array}$ & $\begin{array}{l}0.119 \\
(5.99) \\
\end{array}$ & $\begin{array}{l}0.125 \\
(6.59) \\
\end{array}$ & $\begin{array}{l}0.134 \\
(4.88) \\
\end{array}$ & $\begin{array}{l}0.156 \\
(4.24) \\
\end{array}$ \\
\hline & Characteristics & $\begin{array}{l}0.022 \\
(0.46) \\
\end{array}$ & $\begin{array}{l}0.027 \\
(1.03) \\
\end{array}$ & $\begin{array}{l}0.024 \\
(1.17) \\
\end{array}$ & $\begin{array}{l}0.024 \\
(1.28) \\
\end{array}$ & $\begin{array}{l}0.022 \\
(1.22) \\
\end{array}$ & $\begin{array}{l}0.026 \\
(1.54) \\
\end{array}$ & $\begin{array}{l}0.026 \\
(1.68) \\
\end{array}$ & $\begin{array}{l}0.033 \\
(1.68) \\
\end{array}$ & $\begin{array}{l}0.065 \\
(1.35) \\
\end{array}$ \\
\hline & Coefficients & $\begin{array}{l}0.202 \\
(7.05) \\
\end{array}$ & $\begin{array}{r}0.137 \\
(11.02) \\
\end{array}$ & $\begin{array}{r}0.133 \\
(11.37) \\
\end{array}$ & $\begin{array}{r}0.122 \\
(11.71) \\
\end{array}$ & $\begin{array}{r}0.120 \\
(13.01) \\
\end{array}$ & $\begin{array}{r}0.093 \\
(10.39) \\
\end{array}$ & $\begin{array}{r}0.099 \\
(13.88) \\
\end{array}$ & $\begin{array}{r}0.101 \\
(13.82) \\
\end{array}$ & $\begin{array}{l}0.092 \\
(6.08) \\
\end{array}$ \\
\hline \multirow{3}{*}{ 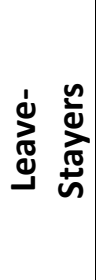 } & $\begin{array}{l}\text { Earnings } \\
\text { Differential }\end{array}$ & $\begin{array}{l}0.118 \\
(3.60) \\
\end{array}$ & $\begin{array}{l}0.065 \\
(2.72) \\
\end{array}$ & $\begin{array}{l}0.044 \\
(2.36) \\
\end{array}$ & $\begin{array}{l}0.037 \\
(1.81) \\
\end{array}$ & $\begin{array}{l}0.038 \\
(1.80) \\
\end{array}$ & $\begin{array}{l}0.047 \\
(2.26) \\
\end{array}$ & $\begin{array}{l}0.066 \\
(2.77) \\
\end{array}$ & $\begin{array}{l}0.147 \\
(3.75) \\
\end{array}$ & $\begin{array}{l}0.324 \\
(7.81) \\
\end{array}$ \\
\hline & Characteristics & $\begin{array}{l}-0.007 \\
(-0.18) \\
\end{array}$ & $\begin{array}{l}0.011 \\
(0.44) \\
\end{array}$ & $\begin{array}{l}0.017 \\
(0.88) \\
\end{array}$ & $\begin{array}{l}0.020 \\
(1.11) \\
\end{array}$ & $\begin{array}{l}0.026 \\
(1.48) \\
\end{array}$ & $\begin{array}{l}0.042 \\
(2.53) \\
\end{array}$ & $\begin{array}{l}0.049 \\
(2.97) \\
\end{array}$ & $\begin{array}{l}0.099 \\
(3.07) \\
\end{array}$ & $\begin{array}{l}0.298 \\
(5.94) \\
\end{array}$ \\
\hline & Coefficients & $\begin{array}{l}0.125 \\
(4.42)\end{array}$ & $\begin{array}{l}0.054 \\
(4.21)\end{array}$ & $\begin{array}{l}0.027 \\
(2.25)\end{array}$ & $\begin{array}{l}0.017 \\
(1.59)\end{array}$ & $\begin{array}{l}0.012 \\
(1.25)\end{array}$ & $\begin{array}{l}0.006 \\
(0.61)\end{array}$ & $\begin{array}{l}0.018 \\
(2.45)\end{array}$ & $\begin{array}{l}0.048 \\
(6.64)\end{array}$ & $\begin{array}{l}0.026 \\
(1.84)\end{array}$ \\
\hline \multirow{3}{*}{ 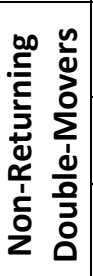 } & $\begin{array}{l}\text { Earnings } \\
\text { Differential }\end{array}$ & $\begin{array}{l}0.137 \\
(2.71) \\
\end{array}$ & $\begin{array}{l}0.147 \\
(4.34) \\
\end{array}$ & $\begin{array}{l}0.154 \\
(5.70) \\
\end{array}$ & $\begin{array}{l}0.146 \\
(6.91) \\
\end{array}$ & $\begin{array}{l}0.146 \\
(7.52) \\
\end{array}$ & $\begin{array}{l}0.145 \\
(8.46) \\
\end{array}$ & $\begin{array}{l}0.150 \\
(8.34) \\
\end{array}$ & $\begin{array}{l}0.162 \\
(8.97) \\
\end{array}$ & $\begin{array}{l}0.156 \\
(6.35) \\
\end{array}$ \\
\hline & Characteristics & $\begin{array}{l}-0.021 \\
(-0.43)\end{array}$ & $\begin{array}{l}0.012 \\
(0.45)\end{array}$ & $\begin{array}{l}0.014 \\
(0.66)\end{array}$ & $\begin{array}{l}0.009 \\
(0.49)\end{array}$ & $\begin{array}{l}0.005 \\
(0.31)\end{array}$ & $\begin{array}{l}0.011 \\
(0.70)\end{array}$ & $\begin{array}{l}0.019 \\
(1.21)\end{array}$ & $\begin{array}{l}0.034 \\
(1.85)\end{array}$ & $\begin{array}{l}0.047 \\
(1.62)\end{array}$ \\
\hline & Coefficients & $\begin{array}{l}0.158 \\
(5.39)\end{array}$ & $\begin{array}{r}0.136 \\
(10.18)\end{array}$ & $\begin{array}{r}0.139 \\
(11.64)\end{array}$ & $\begin{array}{r}0.137 \\
(12.83)\end{array}$ & $\begin{array}{r}0.143 \\
(15.20)\end{array}$ & $\begin{array}{r}0.134 \\
(14.91)\end{array}$ & $\begin{array}{r}0.131 \\
(18.21)\end{array}$ & $\begin{array}{r}0.128 \\
(16.94)\end{array}$ & $\begin{array}{l}0.109 \\
(7.22)\end{array}$ \\
\hline
\end{tabular}

Note: t-statistics, derived from bootstrapped standard errors with 1,000 repetitions, are in parenthesis. 